\title{
A Special Case of Cirrhosis with a Novel ATP7B Mutation and Occult Chronic HBV Infection
}

\author{
Yongfang Jiang, Mengxuan Chen, Yelin Ruan, Jing Ma and Naiping Li \\ Department of Infectious Disease, The Second Xiangya Hospital of Central South University, Changsha, China
}

\begin{abstract}
Wilson's disease (WD) is an autosomal recessive disorder that affects copper metabolism. Mutations of the ATP7B gene have been found to be strongly associated with a risk of developing WD; and at present, more than 500 mutations have been reported in WD patients. The Arg778Leu and Arg952Lys mutations in exons 8 and 12, respectively, are highly prevalent in the Chinese population. However, early detection of WD is difficult due to the extreme variations in mutations of ATP7B, and the lack of specific clinical symptoms during the early stages of the disease. Meanwhile, the early stage of occult hepatitis B infection lacks typical clinical manifestations, which easily leads to it being misdiagnosed as liver cirrhosis. We report a new pathogenic exon 19 mutation of $A T P 7 B \square$ which can potentially contribute to the early genetic diagnosis and prompt treatment of WD.
\end{abstract}

Key Words: Wilson's disease, Gene mutation, ATP7B, Cirrhosis, Occult hepatitis B infection.

How to cite this article: Jiang Y, Chen M, Ruan Y, Ma J, Li N. A Special Case of Cirrhosis with a Novel ATP7B Mutation and Occult Chronic HBV Infection. J Coll Physicians Surg Pak 2021; 31(10):1231-1233.

\section{INTRODUCTION}

Wilson's disease (WD) is an autosomal recessive disease caused by impaired copper transport. ${ }^{1}$ The $A T P 7 B$ gene located on chromosome 13 encodes, a P-type ATPase, which is involved in the synthesis of holo-ceruloplasmin and copper excretion. More than 500 ATP7B gene mutations have been identified at present in WD patients, and 380 of these mutations have been confirmed to play a pathogenic role. ${ }^{2}$ Although most patient$\mathrm{s}$, aged from 5 to 35 years, are symptomatic, the early stages of the disease are often asymptomatic, resulting in misdiagnoses. WD is one of the few genetic diseases, for which early diagnosis and timely treatment can significantly improve prognosis. ${ }^{3}$ However, at present, the diagnosis of WD depends on clinical manifestations and biochemical tests, which may delay proper diagnosis and treatment. We report a case of an adult patient with occult hepatitis B virus (HBV) infection and $W D$, who harboured a previously unknown mutation of the ATP7B gene.

\section{CASE REPORT}

A 27-year male with known bronchiectasis and diagnosed withHBV infection two months prior, presented with persistent jaundice, adynamia and darkurine for 15 days.

Correspondence to: Mengxuan Chen, Department of Infectious Disease, The Second Xiangya Hospital of Central

South University, Changsha, China

E-mail: a137987219@csu.edu.cn

Received: October 22, 2019; Revised: October 18, 2020;

Accepted: October 23, 2020

DOI: https://doi.org/10.29271/jcpsp.2021.10.1231
The patient had been consuming moderate amount of alcohol during the previous three years and had been a smoker for 10 years. The patient has donated blood for many years and tested as HBsAg-negative each time. A physical examination did not reveal any specific condition. Quantitation of HBV markers in serum were positive for $\mathrm{HBsAb}$ and $\mathrm{HBeAg}$, but negative for others. The serum HBV-DNA level was $1.35 \times 10^{6} \mathrm{IU} / \mathrm{ml}$. Liver function tests showed slightly elevated levels of aminotransferases and serum bilirubin, while coagulation test$s$ showed a prolonged prothrombin time. The autoimmune liver disease tests were all negative. In addition, alpha-fetoprotein (AFP) level was $235 \mathrm{IU} / \mathrm{ml}$, and ceruloplasmin (CER) was $27.3 \mathrm{mg} / \mathrm{ml}$. Ultrasonography showed liver parenchyma with a spot thickening distribution and the serum ceruloplasmin level was low. To further clarify whether the patient with HBV infection suffered from concurrent WD, we performed DNA sequencing for HBV and $A T P 7 B$. HBV $S$ region sequencing showed no pathogenic mutations, while $A T P 7 B$ gene sequencing revealed a novel c.3910 $\mathrm{T}<\mathrm{A}$ (Leu1304Met) mutation at exon 19 (Figure 1).

Irregular hepatic plates, and numerous focal necrosis and smallnecrotic patches were observed in the hepatic lobules. Bridging and confluent necrosis were rarely observed. Lymphocytic infiltration and severe plate inflammation were observed in the portalareas.

The patient was referred for liver biopsy and copper level testing. Histological examination showed active liver cirrhosis (Figure 2) Copper levels were $3,017 \mu \mathrm{g} / \mathrm{ml}, 310 \mathrm{ug} / 24$ $\mathrm{h}$ and $667 \mathrm{ug} / \mathrm{g}$ in serum, urine, and liver tissue, respectively. The patient was eventually diagnosed with mixed cirrhosis (occult HBV infection and WD). The patient was adminis- 
tered 500 mg entecavir and sodium dimercaptopropane sulfonate daily for the first five days.

In the months following treatment, the patient showed a modest increase in serum levels of copper, decline in HBVDNA load, and a decrease in alkaline phosphatase and alanine aminotransferase levels (Table I).

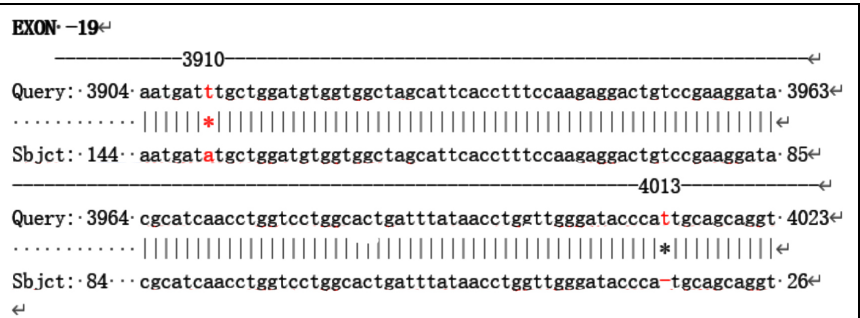

Figure 1: Comparative analysis of ATP7B gene sequences.

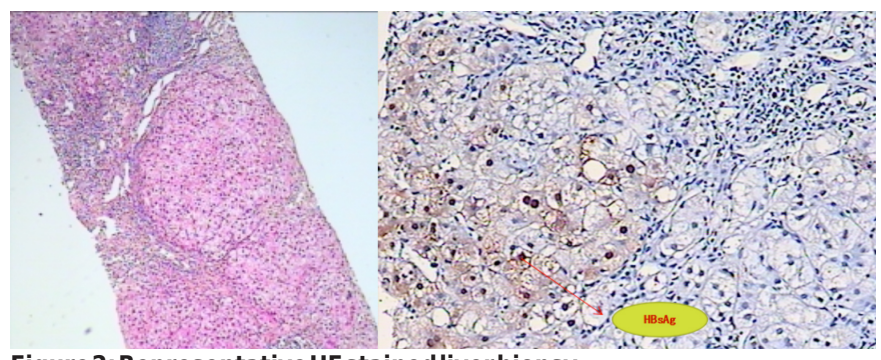

Figure 2: Representative HE stained liver biopsy.

Table I: After treatment with entecavir and sodium dimercaptopropane sulfonate, the quantification of hepatitis B virus, ceruloplasmin and liver function of patient were conducted at follow-up. The level of ceruloplasmin decreased after treatment, but the level of transaminases fluctuated, while treatment was able to maintain copper and antiviral levels. The liver function of the patient gradually recovered.

\begin{tabular}{|c|c|c|c|c|}
\hline Date & $\begin{array}{c}\text { HBV-DNA } \\
\text { (IU/mI) }\end{array}$ & HBV profile & $\begin{array}{c}\text { Ceruloplasmin } \\
\text { (mg/mI) }\end{array}$ & $\begin{array}{c}\text { Liver } \\
\text { function } \\
\text { (U/L) }\end{array}$ \\
\hline 2018.01 .28 & $1.79 \times 10^{3}$ & $\begin{array}{c}\text { HBsAb, } \\
\text { HBeAg(+), } \\
\text { HBclgG(+) }\end{array}$ & 60.3 & normal \\
\hline 2018.03 .05 & $\begin{array}{c}\text { Lower than } \\
10\end{array}$ & $\begin{array}{c}\text { HBsAb, } \\
\text { HBeAg(+), } \\
\text { HBclgG(+) }\end{array}$ & 62.4 & $\begin{array}{c}\text { ALT:91.5, } \\
\text { AST: } 27.1\end{array}$ \\
\hline 2018.05 .28 & $\begin{array}{c}\text { Lower than } \\
10\end{array}$ & $\begin{array}{c}\text { HBsAb(+), } \\
\text { HBclgG(+) }\end{array}$ & 56.5 & $\begin{array}{c}\text { ALT:71, } \\
\text { AST:31.2 }\end{array}$ \\
\hline 2018.08 .21 & $\begin{array}{c}\text { Lower than } \\
10\end{array}$ & $\begin{array}{l}\text { HBsAb(+), } \\
\text { HBclgG(+) }\end{array}$ & 58.4 & $\begin{array}{c}\text { ALT:57.1, } \\
\text { AST:15.1 }\end{array}$ \\
\hline
\end{tabular}

\section{DISCUSSION}

WD is an inherited autosomal recessive disease involving copper metabolism that is more prevalent in consanguineous communities. The global prevalence of WD is estimated to be between $1 / 30,000$ to $1 / 100,000^{4}$, and is high in China, compared with Western countries. ${ }^{3}$ The primary gene involved in WD is adenosine triphosphatase or ATP7B, which is located on chromosome 13q14.3 and encodes a P-type copper transporter. According to Mallikarjun et al., more than 500 ATP7B mutations have been identified in WD patients at present ${ }^{2}$, which can cause decreased serum ceruloplasmin levels and copper overload in the liver, leading to various clinical manifestations of WD. ${ }^{5}$ Therefore, the possibility of WD should be considered in cases of abnormal liver function, ${ }^{6}$ idiopathic hepatic dysfunction or neuromotor disturbances, and should not be excluded only on the basis of the age of onset. A significant decrease in serum ceruloplasmin level is one of strongest indicators of WD.

The patient showed atypical clinical manifestations and presented with abnormal HBV infection. We identified a novelp.Leu1304 Met mutation on exon 19 using DNA sequencing. However, we did not test the introns and promoters, which are rarely mutated in the ATP7B gene. ${ }^{4}$ The patient was also suffering from occult chronic HBV infection, which could have skewed the clinical manifestations and test indices.

Since HBsAg was used as the single screening standard for HBV, this patient was not diagnosed with hepatitis B until 2015. Therefore, for patients with elevated liver enzyme level$\mathrm{s}$, the serum ceruloplasmin levels should also be checked, regardless of the HBV index. In addition, the ATP7B gene should be screened for mutations if the symptoms and test results are atypical. DNA sequencing of the ATP7B gene to identify mutations is a sensitive, specific, and non-invasive method for the early diagnosis of WD.

$\mathrm{HBV}$ is the most common form of hepatitis that causes cirrhosis in China, and a reduction in ceruloplasmin levels may indicate HBV infection. However, reduced levels of serum ceruloplasmin do not necessarily indicate WD. For patients with chronic liver disease, determination of etiology is of clinical significance. Approximately $20 \%$ of ATP7B gene carriers, $4.15 \%$ of chronic hepatitis and $10.87 \%$ of hepatic cirrhosis patients and some patients with rare genetic diseases may show a decrease in the level of serum ceruloplasmin. Nevertheless, its levels rarely reach less than $50 \%$ of the lower limit of the normal referencerange (i.e., $<80 \mathrm{mg} / \mathrm{L}$ ). ${ }^{7-9}$

WD-associated cirrhosis causes less damage to liver function compared with hepatitis B-associated cirrhosis, although it carries a higher risk of extrahepatic manifestations. ${ }^{10}$ Since the treatment effect was significant, for patients with elevated levels of serum liver enzymes, a serum ceruloplasmin test should be carried out. If the result is abnormal, urine copper quantification and $A T P 7 B$ gene screening should be further employed to detect WD at an early stage.

\section{PATIENT'S CONSENT:}

Verbal consent of the patient was obtained.

\section{CONFLICT OF INTEREST:}

The authors declared no conflict of interest.

\section{AUTHORS' CONTRIBUTION:}

All authors participated in the writing of the paper.

\section{REFERENCES}

1. Bao $Y$, Chen $L, Y u ~ Y$, Jiang $H$, Guan $T$, Fang C. Novel ATP7B gene mutations in Chinese Han patients with hepatolenticular degeneration. Neural Regeneration Res 2010; 5.933-7. 
2. Patil M, Sheth KA, Krishnamurthy AC, Devarbhavi H. A review and current perspective on Wilson disease. J Clin Exp Hepatol 2013; 3(4):321-36. doi: 10.1016/j.jceh. 2013.06.002.

3. Xie J, Wu ZY. Wilson's Disease in China. Neurosci Bull 2017; 33(3): 323-30. doi: 10.1007/s12264-017-0107-4.

4. Coffey AJ, Durkie M, Hague S, McLay K, Emmerson J, Klaffke $\mathrm{S}$, et al. A genetic study of Wilson's disease in the United Kingdom. Brain 2013; 136(5):1476-87. doi: 10.1093/ brain/awt035.

5. Xiao H, Deng S, Deng X, Gu S, Yang Z, Yin H, et al. Mutation analysis of the $A T P 7 B$ gene in seven Chinese Families with Wilson's Disease. Digestion 2019; 99(4):319-26. doi: $10.1159 / 000493314$.

6. Seto WK, Miu Mak C, But D, Hung I, Wan Lam C, Tam S, et al. Mutational analysis for Wilson's disease. Lancet 2009; 374(9690):662. doi: 10.1016/S0140-6736(09)60915-6.
7. Golovanova EV, Lazebnik LB, Konev YV, Shaposhnikova NA. Wilson's disease (hepatolenticular degeneration, dystrophia hepatocerebralis) diagnosis, treatment, and dispensary observation. Guidelines were approved by the $x v$ gastroenterological scientific society of Russia in 2015. Eksp Klin Gastroenterol 2015; 7:108-11.

8. Yang X, Tong DJ, Liang J, Zhang YH, Lei JH, He XE, et al. Ceruloplasmin level of patients with liver disease in China. Chinese J Inter Med 2005; 44(1):13-5.

9. Xu R, Jiang YF, Zhang YH, Yang X. The optimal threshold of serum ceruloplasmin in the diagnosis of Wilson's disease: $A$ large hospital-based study. PLoS One 2018; 13(1): e0190887. doi: 10.1371/journal.pone.0190887.

10. Zhong HJ, Sun HH, Xue LF, McGowan EM, Chen Y. Differential hepatic features presenting in Wilson diseaseassociated cirrhosis and hepatitis B-associated cirrhosis. World J Gastroenterol 2019; 25(3):378-87. doi: 10.3748/ wjg.v25.i3.378. 